\title{
Karakteristik Infeksi HIV Anak di Unit Rawat Inap SMF Kesehatan Anak RSUP Fatmawati Tahun 2005-2006
}

\author{
Debbie Latupeirissa \\ SMF Kesehatan Anak RSUP Fatmawati, Jakarta
}

\begin{abstract}
Latar belakang. Infeksi HIV baru pada anak di dunia semakin meningkat sejak 4 tahun terakhir, terutama akibat transmisi ibu ke janin saat pre-partum, intrapartum, dan menyusui.

Tujuan. Pengamatan untuk mendapatkan gambaran karakteristik infeksi HIV pada anak di RSUP Fatmawati periode tahun 2005-2006

Metode. Penelitian prospektif terhadap 19 anak dengan anti-HIV selama kurun waktu Juni 2005 - Desember 2006.

Hasil. Di antara 19 pasien dengan anti-HIV positif didapatkan 9 orang anak laki-laki (64,28\%) dan 5 orang anak perempuan (35,72\%). Usia terbanyak adalah usia 0-11 bulan yaitu $6(42,86 \%)$ pasien. Status gizi pasien terbanyak adalah gizi buruk (50\%). Spektrum klinis terbanyak adalah seropositif HIV asimtomatik 9 kasus, dan 4 kasus dengan HIV stadium 3. Infeksi oportunistik tersering adalah tuberkulosis paru pada 10 pasien. Kadar CD4<15\% ditemukan pada semua pasien HIV stadium 3. Pasien yang mendapat antiretroviral (ARV) hanya 8 pasien yang dapat diikuti selama 6 bulan dengan hasil yang sama antara yang mengalami perbaikan klinis dan tidak. Pada penelitian ini angka drop out pasien yang tidak dapat diikuti selama 6 bulan adalah 4 kasus $(28,57 \%)$.

Kesimpulan. Diagnosis presumptif dapat dipakai pada keadaan pemeriksaan anti-HIV belum dapat dilakukan. Tuberkulosis paru merupakan infeksi oportunistik yang paling banyak ditemukan. Hampir separuh pasien mengalami perbaikan klinis setelah pemberian ARV.
\end{abstract}

Sari Pediatri 2012;14(2):117-21.

Kata kunci. HIV, anak, karakteristik

\footnotetext{
Alamat korespondensi:

Dr. Debbie Latupeirissa, Sp.A. SMF Kesehatan Anak RSUP Fatmawati, Jakarta. Telp. (021) 7501524, Fax.: (021)75911454 E-mail: debbie_ latupeirissa@yahoo.com
}

I nfeksi HIV baru pada anak di dunia pada tahun 2008 diperkirakan sekitar 430.000 (240.000610.000). Sembilan puluh persen antaranya ditularkan melalui transmisi ibu ke bayi. Dari jumlah tersebut, 280.000-360.000 infeksi didapat saat melahirkan dan periode pre-partum dan sisanya didapat 
saat menyusui. ${ }^{1}$ Di Indonesia jumlah kumulatif kasus infeksi HIV di Indonesia sampai bulan September 2010 adalah 22726 kasus dan prevalensi kasus AIDS nasional per 100.000 penduduk adalah 9,85. Angka ini lebih tinggi 3 kali dibandingkan prevalensi pada tahun 2006 yaitu sebanyak 3,47. ${ }^{2}$ Pada anak berusia di bawah 5 tahun terdapat 500 kasus AIDS dan usia di bawah 1 tahun sebanyak 227 kasus. Hal ini sesuai dengan angka transmisi ibu ke janin yaitu sebanyak $1 \%$ dari jumlah kumulatif.,3

Surveilens tentang HIV/AIDS tahun 2005, oleh dr. Endang Poejiningsih di klinik Wijaya Kusuma RS Fatmawati dan di ruang rawat inap RS Fatmawati tahun 2005 menunjukkan total kunjungan 397 dengan angka proporsi $0,13 \%$ dari seluruh kunjungan pasien di RS Fatmawati tahun 2005 dan yang memiliki faktor risiko sebanyak 324 pasien (81,61\%). Dari 313 $(96,6 \%)$ pasien yang setuju dilakukan pemeriksaan anti HIV diperoleh 240 pasien $(76,7 \%)$ dengan anti HIV positif dan 70 pasien $(22,4 \%)$ dengan anti HIV negatif. Faktor risiko terbanyak pasien dengan anti HIV positif adalah injective drug users (IDU) sebanyak 209 kasus $(74,7 \%)$. Usia tertinggi yaitu 18-35 tahun sebanyak 222 kasus (92,5\%). ${ }^{4}$ Surveilens terhadap pasien anak dengan infeksi HIV belum dilakukan tetapi kasusnya makin meningkat sejak tahun 2005. Sejak Juni 2005 - Desember 2006 tercatat 23 kasus anak yang diduga infeksi HIV dan 19 pasien dengan hasil pemeriksaan anti HIV positif. Penelitian ini bertujuan untuk menggambarkan karakteristik infeksi HIV pada anak di SMF Kesehatan Anak RSUP Fatmawati yang dirawat pada periode 2005-2006.

\section{Metodologi penelitian}

Desain penelitian kohort prospektif jangka pendek. Sumber data didapatkan dari anamnesis, pemeriksaan fisis dan pemeriksaan penunjang yang dilakukan terhadap populasi terjangkau. Populasi terjangkau adalah semua pasien yang terbukti pemeriksaan anti HIV reaktif atau bayi baru lahir dengan hasil pemeriksaan anti HIV seropositif di unit rawat inap SMF Anak RSUP Fatmawati, Jakarta selama kurun waktu 1 tahun yaitu Juni 2005 - Desember 2006. Data yang dicatat adalah usia, jenis kelamin, status gizi, kadar CD4 (\%), diagnosis, infeksi oportunistik, perbaikan klinis setelah 6 bulan pemberian terapi antiretroviral, angka drop out. Setiap pasien diikuti setiap bulannya saat mereka kontrol di poliklinik sampai 6 bulan sejak diberikan terapi antiretroviral. Diagnosis ditegakkan menggunakan kriteria klinis menurut WHO dan atau status imunologisnya dari kadar CD4.

\section{Hasil penelitian}

Selama periode 1 Juni 2005 - 31 Desember 2006 tercatat 19 kasus seropositif yang dirawat di Unit Rawat Inap SMF Kesehatan Anak RSUP Fatmawati. Dari 19 kasus terdapat anak laki-laki lebih banyak dibandingkan anak perempuan yaitu 12 pasien $(63,17 \%)$ laki-laki dan 7 pasien $(36,83 \%)$ perempuan. Sebaran usia terbanyak pada usia 0-6 bulan 7 pasien (36,83\%), diikuti usia $\geq 18$ bulan 9 pasien (47,37\%), usia 13-17 bulan 2 pasien (10,52\%) dan usia 7-12 bulan 1 kasus $(5,26 \%)$ (Tabel 1). Status nutrisi terbanyak adalah gizi baik 12 kasus $(63,16 \%)$ dan gizi buruk pada 5 kasus (26,31\%) (Tabel 2).

Spektrum klinis diagnosis HIV terbanyak adalah seropositif sebanyak 9 kasus (9/19), diikuti HIV stadium III 7 kasus (7/19) (Tabel 3).

Infeksi oportunistik terbanyak adalah tuberkulosis paru (10/19), diikuti oral thrush (7/19), hepatitis C (1/19) dan Otitis media supuratif kronik(OMSK) $(2 / 19)$.

Tabel 1. Sebaran jenis kelamin berdasarkan usia pada pasien infeksi HIV

\begin{tabular}{lccc}
\hline \multirow{2}{*}{ Usia (bulan) } & \multicolumn{2}{c}{ Jenis kelamin } & Jumlah \\
\cline { 2 - 3 } & perempuan & laki-laki & $(\mathrm{n})$ \\
\hline $0-6$ & 3 & 4 & 7 \\
$7-12$ & 1 & 0 & 1 \\
$13-17$ & 1 & 1 & 2 \\
$\geq 18$ & 2 & 7 & 9 \\
\hline Jumlah & 7 & 12 & 19 \\
\hline
\end{tabular}

Tabel 2. Sebaran status nutrisi pada pasien infeksi HIV

\begin{tabular}{lcccc}
\hline \multirow{2}{*}{ Usia (bulan) } & \multicolumn{3}{c}{ Status nutrisi } & Jumlah \\
\cline { 2 - 4 } & baik & kurang & buruk & (n) \\
\hline $0-6$ & 7 & 0 & 0 & 7 \\
$7-12$ & 0 & 0 & 1 & 1 \\
$13-17$ & 0 & 0 & 2 & 2 \\
$\geq 18$ & 5 & 2 & 2 & 9 \\
\hline Jumlah & 12 & 2 & 5 & 19 \\
\hline
\end{tabular}


Tabel 3. Sebaran stadium klinis berdasarkan usia pada pasien infeksi HIV

\begin{tabular}{|c|c|c|c|c|c|}
\hline \multirow{2}{*}{ Usia (bulan) } & \multicolumn{4}{|c|}{ Diagnosis awal } & \multirow{2}{*}{$\begin{array}{c}\text { Jumlah } \\
\text { (n) }\end{array}$} \\
\hline & Seropositif & HIV I & HIV 2 & HIV 3 & \\
\hline $0-6$ & 7 & 0 & 0 & 0 & 7 \\
\hline $7-12$ & 0 & 0 & 1 & 0 & 1 \\
\hline $13-17 n$ & 2 & 0 & 0 & 0 & 2 \\
\hline$\geq 18$ & 0 & 2 & 0 & 7 & 9 \\
\hline Jumlah & 9 & 2 & 1 & 7 & 19 \\
\hline
\end{tabular}

Tabel 4.Gambaran infeksi oportunistik pada pasien infeksi HIV

\begin{tabular}{lc}
\hline Diagnosis klinis & Jumlah \\
\hline Oral thrush & 7 \\
TB paru & 10 \\
Hepatitis C & 1 \\
OMSK & 2 \\
\hline
\end{tabular}

Kadar CD4 berdasarkan diagnosis, maka imunodefisiensi berat $(<15 \%)$ terdapat pada 9 kasus (47,3\%) dengan diagnosis HIV stadium 1 dan 3, dan $88,9 \%$ diantaranya pada HIV stadium 3 (Tabel 5)

Pasien yang mendapat terapi ARV sebanyak 11 pasien dan 8 pasien tidak mendapat ARV. Setelah 6 bulan pengamatan, ada 7 pasien yang tidak ada data karena tidak kontrol ulang, dan 12 pasien yang dapat diamati perjalanan klinisnya. Sembilan pasien yang mendapat ARV lini pertama, $6(6 / 12)$ pasien mengalami perbaikan klinis dan 3 pasien tidak (3/12).

Monitoring laboratoris tidak dapat diamati karena hampir semua pasien hasil pemeriksaan laboratorium tidak lengkap, ada pasien yang drop out dan tidak ada yang meninggal.

\section{Pembahasan}

Penelitian ini merupakan suatu model untuk penelitian jangka panjang terhadap semua pasien anak seropositif HIV dan bayi yang lahir dari ibu dengan HIV positif di SMF Kesehatan Anak RSUP Fatmawati, Jakarta.

Diagnosis HIV terbanyak yaitu seropositif pada kelompok usia 0-17 bulan (9/19), Cara menegakkan diagnosis infeksi HIV pada anak tergantung usia. Penentuan diagnosis HIV paa anak dengan

Tabel 5. Sebaran hasil CD4\% berdasarkan stadium klinis pada pasien infeksi HIV

\begin{tabular}{lcccc}
\hline Diagnosis awal & \multicolumn{3}{c}{ CD4 awal\% } & Jumlah \\
\cline { 2 - 4 } & Tidak ada data & $<15$ & $>20$ & $(\mathrm{n})$ \\
\hline Sero+ & 4 & 0 & 5 & 9 \\
HIV I & 1 & 0 & 1 & 2 \\
HIV 2 & 0 & 1 & 0 & 1 \\
HIV 3 & 0 & 7 & 0 & 7 \\
\hline Jumlah & 5 & 9 & 5 & 19 \\
\hline
\end{tabular}

Tabel 6. Sebaran perbaikan klinis setelah 6 bulan pemberian ARV

\begin{tabular}{lcccc}
\hline \multirow{2}{*}{ Terapi Antiretroviral } & \multicolumn{3}{c}{ Perbaikan klinis pasca 6 bln } & Jumlah \\
\cline { 2 - 4 } & Tidak ada data & Ya & Tidak & (n) \\
\hline Lini awal & 2 & 6 & 3 & 11 \\
Tanpa ARV & 5 & 2 & 1 & 8 \\
\hline Jumlah & 7 & 8 & 4 & 19 \\
\hline
\end{tabular}


Tabel 3. Sebaran stadium klinis berdasarkan usia pada pasien infeksi HIV

\begin{tabular}{|c|c|c|c|c|c|}
\hline \multirow{2}{*}{ Usia (bulan) } & \multicolumn{4}{|c|}{ Diagnosis awal } & \multirow{2}{*}{$\begin{array}{c}\text { Jumlah } \\
\text { (n) }\end{array}$} \\
\hline & Seropositif & HIV I & HIV 2 & HIV 3 & \\
\hline $0-6$ & 7 & 0 & 0 & 0 & 7 \\
\hline $7-12$ & 0 & 0 & 1 & 0 & 1 \\
\hline $13-17 n$ & 2 & 0 & 0 & 0 & 2 \\
\hline$\geq 18$ & 0 & 2 & 0 & 7 & 9 \\
\hline Jumlah & 9 & 2 & 1 & 7 & 19 \\
\hline
\end{tabular}

Tabel 4.Gambaran infeksi oportunistik pada pasien infeksi HIV

\begin{tabular}{lc}
\hline Diagnosis klinis & Jumlah \\
\hline Oral thrush & 7 \\
TB paru & 10 \\
Hepatitis C & 1 \\
OMSK & 2 \\
\hline
\end{tabular}

Kadar CD4 berdasarkan diagnosis, maka imunodefisiensi berat $(<15 \%)$ terdapat pada 9 kasus (47,3\%) dengan diagnosis HIV stadium 1 dan 3, dan $88,9 \%$ diantaranya pada HIV stadium 3 (Tabel 5)

Pasien yang mendapat terapi ARV sebanyak 11 pasien dan 8 pasien tidak mendapat ARV. Setelah 6 bulan pengamatan, ada 7 pasien yang tidak ada data karena tidak kontrol ulang, dan 12 pasien yang dapat diamati perjalanan klinisnya. Sembilan pasien yang mendapat ARV lini pertama, $6(6 / 12)$ pasien mengalami perbaikan klinis dan 3 pasien tidak (3/12).

Monitoring laboratoris tidak dapat diamati karena hampir semua pasien hasil pemeriksaan laboratorium tidak lengkap, ada pasien yang drop out dan tidak ada yang meninggal.

\section{Pembahasan}

Penelitian ini merupakan suatu model untuk penelitian jangka panjang terhadap semua pasien anak seropositif HIV dan bayi yang lahir dari ibu dengan HIV positif di SMF Kesehatan Anak RSUP Fatmawati, Jakarta.

Diagnosis HIV terbanyak yaitu seropositif pada kelompok usia 0-17 bulan (9/19), Cara menegakkan diagnosis infeksi HIV pada anak tergantung usia. Penentuan diagnosis HIV paa anak dengan

Tabel 5. Sebaran hasil CD4\% berdasarkan stadium klinis pada pasien infeksi HIV

\begin{tabular}{lcccc}
\hline Diagnosis awal & \multicolumn{3}{c}{ CD4 awal\% } & Jumlah \\
\cline { 2 - 4 } & Tidak ada data & $<15$ & $>20$ & $(\mathrm{n})$ \\
\hline Sero+ & 4 & 0 & 5 & 9 \\
HIV I & 1 & 0 & 1 & 2 \\
HIV 2 & 0 & 1 & 0 & 1 \\
HIV 3 & 0 & 7 & 0 & 7 \\
\hline Jumlah & 5 & 9 & 5 & 19 \\
\hline
\end{tabular}

Tabel 6. Sebaran perbaikan klinis setelah 6 bulan pemberian ARV

\begin{tabular}{lcccc}
\hline \multirow{2}{*}{ Terapi Antiretroviral } & \multicolumn{3}{c}{ Perbaikan klinis pasca 6 bln } & Jumlah \\
\cline { 2 - 4 } & Tidak ada data & Ya & Tidak & (n) \\
\hline Lini awal & 2 & 6 & 3 & 11 \\
Tanpa ARV & 5 & 2 & 1 & 8 \\
\hline Jumlah & 7 & 8 & 4 & 19 \\
\hline
\end{tabular}


menggunakan pemeriksaan ELISA anti-HIV tidak dapat digunakan pada anak usia $<18$ bulan karena masih terdapatnya antibodi ibu sampai usia 18 bulan. Antibodi ibu akan menurun secara bertahap dan kadang-kadang tidak terukur lagi pada bayi berusia 7 sampai 10 bulan, tetapi umumnya menetap pada bayi berusia 18 bulan yang terinfeksi atau tidak. Pada kelompok usia ini penegakkan diagnosis HIV sebaiknya menggunakan pemeriksaan PCR DNA dan atau RNA. ${ }^{5-6}$ Pada kelompok usia 0-17 bulan, ditemukan 1 kasus dengan HIV stadium 2. Sekalipun tidak ada pemeriksaan PCR untuk menegakkan diagnosis pasien ini, WHO telah merekomendasikan diagnosis presumptif berdasarkan penemuan klinis saja, tetapi pada saat pasien berusia 18 bulan, tetap harus dikonfirmasi dengan pemeriksaan serologis. ${ }^{6}$

Pada kelompok usia $\geq 18$ bulan setelah diagnosis pasti dapat ditegakkan dengan pemeriksaan serologis, didapatkan 9 pasien terinfeksi HIV (47,36\%). Oleh karena infeksi HIV pada anak terjadi akibat transmisi ibu ke bayinya saat prepartum, intrapartum dan postpartum, maka angka di atas dapat menggambarkan angka transmisi HIV dari ibu ke bayinya. Penelitian sebelumnya mendapatkan transmisi perinatal di USA dan negara maju sekitar 15-25\%, sedangkan di Afrika dan Haiti adalah 25-40\%.7 Oleh karena Indonesia termasuk negara sedang berkembang, maka angka transmisi yang didapat hampir sama dengan transmisi di Afrika dan Haiti

Selain pemeriksaan serologis, diagnosis ditentukan juga berdasarkan penemuan klinis yaitu adanya infeksi oportunistik seperti oral thrush, tuberkulosis paru, hepatitis C, dan otitis media supurativa kronik. Prevalensi infeksi oportunisitik tuberkulosis paru anak adalah $79-81 \%$ diantara usia $<18$ bulan, $50-64 \%$ pada usia 19 bulan-9 tahun, dan 19\% pada usia 10-14 tahun. Dari data ini terlihat bahwa prevalens tertinggi pada anak usia termuda ( $<18$ bulan). ${ }^{8}$ Prevalens infeksi HIV pada tuberkulosis anak di RSUP Fatmawati tahun 2010 adalah $2 \% .^{9}$

Penelitian kami juga menemukan umumnya pasien memiliki status nutrisi baik yaitu sebanyak 12 kasus $(63,2 \%)$. Hal ini terjadi karena sebagian besar pasien dengan status gizi ini adalah pasien dengan diagnosis seropositif. Semua pasien HIV stadium 3 memiliki status gizi buruk. Penelitian sebelumnya juga melaporkan gizi buruk adalah salah satu gejala klinis pada $17 \%$ AIDS anak. ${ }^{10}$ Hasil laboratorium menunjukkan imunodefisiensi berat (CD4 <15\%) pada semua pasien dengan HIV stadium 3. Pada penelitian ini belum dapat dilihat korelasinya karena jumlah sampel yang sedikit.

Pemantauan klinis setelah 6 bulan pemberian ARV pada 9 pasien, didapatkan 6 pasien mengalami perbaikan klinis, sedangkan 3 orang tidak membaik. Drop out terjadi pada 4 pasien. Umumnya pasca 6 bulan terapi, sering timbul infeksi opurtunistik. Pada 3 kasus yang tidak membaik, hanya 1 pasien yang ditemukan otitis media supurativa kronik, dan lainnya adalah berat badan yang tidak bertambah.

\section{Kesimpulan}

Diagnosis HIV pada anak dapat dilakukan berdasarkan infeksi oportunistik yang menyertainya dan pemeriksaan penunjang. Apabila pemeriksaan serologis dan PCR tidak dapat dilakukan, maka ditegakkan diagnosis presumptif berdasarkan gejala klinis saja setelah itu dipastikan dengan pemeriksaan serologis pada usia $\geq 18$ bulan. Tuberkulosis paru merupakan infeksi oportunistik yang paling banyak ditemukan. Hampir separuh pasien mengalami perbaikan klinis setelah pemberian ART.

\section{Daftar pustaka}

1. Joint United Nations Programme on HIV/AIDS : AIDS epidemic update : 2008.Geneva, World Helath Organization 2008.

2. Ditjen PPM \& PL Depkes RI. Statistik Kasus HIV/AIDS di Indonesia tahun 2010

3. Red Book. Human immunodeficiency virus infection. Red Book 2006. Report of the Committee on Infectious Diseases. h. 378-401

4. Poejiningsih E. Data Statistik pasien di RS Fatmawati tahun 2005.

5. Bartlett JG, Gallant JE. In: 2005-2006 Medical Management of HIV. John Hopkins Medicine, Baltimore, Maryland, USA 2005. h. 22-3.

6. Antiretroviral therapy for HIV infection in infants and children: Towards universal access. Recommendations for a public health approach. WHO 2010 revision.

7. Mofenson LM. Pediatric HIV Infection in Developed and Developing Countries: Epidemiology and Natural History. Dalam: Medical Management of AIDS in Children. Saunders 2003:1-28 
8. Luo C, Chintu C, Bhat G: Seroprevalence of human immunodeficiency virus type I infection in Zambian children with tuberculosis: changing seroprevalence and evaluation of thioacetazone-free regimen. Tubercle Lung Dis 1994;75:110-5.

9. Dharmawan BS, Firmanda D. Angka kejadian TB anak tahun 2010 di SMF Kesehatan Anak RSUP Fatmawati. Diprentasikan pada presentasi poster PIT IV Medan 2011.

10. Grunfeld C, Feingold KR : Metabolic disturbances and wasting in the acquired immunodeficiency syndrome. N Engl J Med 1992;327:329-37. 